Nigerian Journal of Physiological Sciences 22 (1-2):15-18 @Physiological Society of Nigeria, 2007

Available online/abstracted at http://www.biolineinternational.org.br/njps; www.ajol.info/journals.njps; www.cas.org

\title{
ATHEROGENIC POTENTIALS OF SOME NIGERIAN MEALS
}

\section{E.U. EYONG ${ }^{1}$, I. B. UMOH ${ }^{1}$, T. I. OGU ${ }^{2}$, E. E. EDET ${ }^{1}$, M. U. ETENG ${ }^{1}$ and A. O. IGIRI $^{3}$}

\author{
Departments of Biochemistry ${ }^{1}$ Nursing $^{2}$ and Anatomy ${ }^{3}$ \\ College of medical Sciences, University of Calabar, Calabar, Nigeria \\ E-mail: eubana@yahoo.com \\ *Corresponding author.
}

\begin{abstract}
Summary: The atherogenic potentials of peeled grated cocoyam (Xanthosoma maffafa scot) "ekpang nkukwo", pounded yam (Discorea spp) with plain soup "afia efere", and plantain porridge (Musa paradisiaca) "iwuk ukom" meals were investigated. The three meals were fed to three different groups of albino rats of Wistar strain for a period of twenty eight days. A fourth group which served as control was feed with normal rat pellet. The mean total plasma cholesterol level in the pounded yam with plain soup fed group was significantly lower $(\mathrm{P}<0.05)$ when compared to the control and peeled grated cocoyam fed groups. The mean total plasma triglyceride (MTPTG) level in the pounded yam with plain soup fed group was significantly lower $(\mathrm{P}<0.05)$ when compared to the control group. However the MTPTG level in the peeled grated cocoyam and plantain porridge fed groups were comparable to control. The mean HDL-cholesterol level in the peeled grated cocoyam and plantain fed groups were comparable control. The mean LDL-cholesterol level in the peeled grated cocoyam and plantain porridge fed groups was significantly lower $(\mathrm{P}<0.05)$ than the control group. The LDL-cholesterol and VLDL-cholesterol in the pounded yam with plain soup fed group was significantly lower $(\mathrm{P}<0.05)$ when compared to control. These findings suggest low atherogenic potentials of the pounded yam with plain soup meal compared to the peeled grated cocoyam and plantain porridge meals.
\end{abstract}

Key Words: Nigerian meals, total cholesterol, total triacylglycerol, HDL-cholesterol, LDL-cholesterol, VLDL-cholesterol.

\section{Introduction}

The role played by the dietary pattern of a community in the development of the atherosclerotic disease has long been recognized. Evidence from various populations show that various nutrients affect the concentration of plasma lipids and lipoprotein cholesterol level and hence have varying influences on the atherosclerotic disease (Bronste - Steward et al 1995; Fulton, 1978; Ononogbu, 1979; Oliver, 1981; Mensink and Katan, 1987, 1989; Stein etal 1990; Grundy and Denke, 1990). Ononogbu (1979) reported significant differences in the HDL-cholesterol level of Nigerians on typical Nigerian diets when compared to their Caucasian counterparts. Studies with other population groups have also shown marked differences in their lipid profiles. These variations are of interest due to the association of lipid moieties with the atherosclerotic process.

Taylor and Akande (1975) had earlier reported low serum total cholesterol level in Nigerians of low socio-economic status. A similar study by Taylor and Agbedana (1983) reported differences in total cholesterol and HDL-cholesterol of Nigerians on two different socio-economic levels with those on a higher level having higher concentrations of total serum cholesterol. This result deserves attention because of the positive correlation between high total cholesterol level and the atherosclerotic disease. However, earlier studies by William (1971) show less severe atherosclerosis of cerebral and coronary arteries in Nigerians than in Caucasians, but the more recent pathological study by Ogunowo et al. (1986) appear to indicate that there may be an increase in the incidence of coronary heart disease among Nigerians.

Reports on the possible role of Nigerian meals in the aetiology of coronary heart diseases are scanty. However, available evidence appears to postulate low atherogenecity amongst peasant Nigerians who live almost exclusively on peasant meals. Since dietary therapy is the current mainstay for the management and treatment of Coronary heart 
disease, this study is aimed at assessing the atherogenic potentials of three Southern Nigerian meals which are widely consumed within this geographical location. The meals are 'Ekpang nkukwo' (peeled grated cocoyam, xanthasoma maffafa scott) pounded yam (Discorea sp) with 'Afia efere' (plain soup) and 'Iwuk ukom' (Plantain porridge; Musa paradisiaca).

\section{Materials and Methods}

\section{Collection and Preparation of Meals}

The various condiments were obtained from the 'Watt' market, a Municipal market in Calabar, Cross River State and were weighed according to the recipe of Umoh (1972). All the meals were cooked using the traditional cooking methods of the Nigerians who consume these meals.

Grouping and Feeding of Experimental Animals Twenty-four weanling male albino Wistar rats weighing $40-50 \mathrm{~g}$, bred in the Biochemistry departmental animal house were used throughout this study. The rats were divided into four groups of six rats each and were allowed normal daylight cycles. The meals and water were supplied ad libitum.

Group A animals were fed 'Ekpang nkukwo'; group B, pounded yam with 'afia efere'; group C, 'Iwuk ukom' and group D which was the control group as fed rat pellet obtained from Pfizer feed Mill (Nig.) Limited, Aba, Nigeria. The temperature of the animal house was $28 \pm$ $2.0{ }^{\circ} \mathrm{C}$.

Treatment of Animals and Samples for Analysis

At the end of the 28 days feeding period, the rats were anaesthetized in a chloroform chamber and blood (3 - 5ml) obtained by cardiac puncture into clean EDTA bottles (1\% EDTA). This was spun at $7000 \mathrm{~g}$ for 10 minutes. The plasma was aspirated into labeled sample tubes and stored at $-15^{\circ} \mathrm{C}$ for subsequent analysis. All analysis were concluded within 24 hours.

\section{Analysis of Plasma Samples}

All chemicals used were of analytical grade. From the plasma the following parameters were estimated.

i Total plasma cholesterol by the enzymatic colorimetric test (CHOD - PAP) kit method of Siedel et al. (1985) ii HDL-cholesterol concentration after precipitation with Manganese chloride Heparin sulphate by method of Siedel et al (1985).

iii LDL-cholesterol concentration using the relationship of Friedewald et al. (1972).

iv Total triacylglycerol concentration by the method of Sullivan et. al (1995).

v. VLDL-chiolesterol concentration by the relationship of Burnstein and Samaille (1960).

Nutrient composition of all meals was determined using the various methods of the Association of Analytical Chemist (1990).

\section{Statistical Analysis}

The changes in lipid profiles among the various experimental groups were assessed using the one way analysis of variance (ANOVA), while the significance differences between any two groups was assessed by the student t-test. Values of $\mathrm{P}<0.05$ were regarded as significant.

\section{Results}

Results for the various determinations are summarized in tables I and 2. From table 1, the VLDL-cholesterol concentration in all groups was lower compared to control but was significant $(\mathrm{P}<0.05)$ only in the pounded yam with plain soup fed group. The LDL-cholesterol level in the peeled grated cocoyam $(2.05 \pm 0.16$ $\mathrm{mmol} / \mathrm{l})$ and plantain porridge (1.19 \pm 0.00 $\mathrm{mmol} / \mathrm{l}$ ) fed groups was higher compared to control $(1.03 \pm 0.24 \mathrm{mmol} / \mathrm{l})$ while the pounded yam with plain soup fed group recorded a significant $(\mathrm{P}<0.05)$ lower level. The HDLcholesterol levels in all groups were lower than control but was significantly lowered $(\mathrm{P}<0.05)$ in the peeled grated cocoyam and plantain porridge fed groups.

The total plasma cholesterol concentration of the pounded yam with soup fed group $(2.13 \pm$ $0.21 \mathrm{mmol} / \mathrm{l})$ was significantly lower $(\mathrm{P}<0.05)$ than control $(2.54 \pm 0.25 \mathrm{mmol} / \mathrm{l})$ while the peeled grated cocoyam and plantain porridge fed groups recorded higher levels $(3.20 \pm 0.26$ $\mathrm{mmol} / \mathrm{l}$ and $2.64 \pm 0.04 \mathrm{mmol} / \mathrm{l}$ respectively). The total plasma triacylglycerol in all experimental groups was lower compared to control. This low level was significant in the pounded yam with plain soup fed group. 
Atherogenic potentials of some Nigerian Meals

Table I: Total plasma cholesterol, total triacylglycerol and Lipoprotein Cholesterol levels of rats fed the experimental meals.

\begin{tabular}{|c|c|c|c|c|c|c|}
\hline $\begin{array}{l}\text { Group } \\
\quad(n=6)\end{array}$ & $\begin{array}{l}\text { VLDL- } \\
\text { Cholesterol } \\
(\mathrm{mmol} / \mathrm{l})\end{array}$ & $\begin{array}{c}\text { LDL- } \\
\text { Cholesterol } \\
(\mathrm{mmol} / \mathrm{l})\end{array}$ & $\begin{array}{c}\text { HDL- } \\
\text { Cholesterol } \\
(\mathrm{mmol} / \mathrm{l})\end{array}$ & $\begin{array}{c}\text { Total } \\
\text { Cholesterol } \\
(\mathrm{mmol} / \mathrm{l})\end{array}$ & $\begin{array}{c}\text { Total } \\
\text { TG } \\
(\mathrm{mmol} / \mathrm{l})\end{array}$ & $\begin{array}{c}\text { LDL- } \\
\text { Cholesterol } \\
/ \\
\text { HDL- } \\
\text { Cholesterol } \\
\text { ratio } \\
\end{array}$ \\
\hline Control & $0.49 \pm 0.07$ & $1.03 \pm 0.24$ & $1.02 \pm 0.05$ & $2.54 \pm 0.25$ & $1.08 \pm 0.16$ & 1.01 \\
\hline $\begin{array}{l}\text { Peeled grated } \\
\text { cocoyam }\end{array}$ & $0.48 \pm 0.05$ & $2.05 \pm 0.16$ & $0.76 \pm .14 *$ & $3.02 \pm 0.26$ & $1.06 \pm 0.11$ & 2.70 \\
\hline $\begin{array}{l}\text { Pounded yam } \\
\text { with plain } \\
\text { soup }\end{array}$ & $0.40 \pm .04 *$ & $0.76 \pm 0.12$ & $0.97 \pm 0.09$ & $2.13 \pm 0.21$ & $0.89 \pm 0.9 *$ & 0.78 \\
\hline $\begin{array}{l}\text { Plantain } \\
\text { porridge }\end{array}$ & $0.41 \pm 0.04$ & $1.19 \pm 0.00$ & $0.76 \pm 0.04$ & $2.64 \pm 0.04$ & $0.9 \pm 0.09$ & 1.57 \\
\hline
\end{tabular}

Results are presented as Mean $\pm S D$, *Significantly lower than Control $(P<0.05), n=$ number of determinations

Table 2: Crude protein, ether extract, ash and total carbohydrate, content of experimental Meals

\begin{tabular}{ccccc}
\hline MEAL TYPE & $\begin{array}{c}\text { GM/100GM SAMPLE } \\
\text { Pealed grated } \\
\text { cocoyam (Ekpang } \\
n k u k w o)(\mathrm{n}=3)\end{array}$ & $\begin{array}{l}\text { Pounded yam with } \\
\text { white soup (afia } \\
\text { efere }(\mathrm{n}=3)\end{array}$ & $\begin{array}{l}\text { Porridge } \\
\text { plantain (Iwuk } \\
\text { ukom) }(\mathrm{n}=3)\end{array}$ & $\begin{array}{c}\text { Control meal } \\
(\mathrm{n}=3)\end{array}$ \\
\hline Crude Protein & $13.69 \pm 0.54$ & $11.3 \pm 0.10$ & $10.09 \pm 0.14$ & $13.42 \pm 0.50$ \\
Ether Extract & $13.20 \pm 0.15$ & $6.56 \pm 0.31$ & $10.11 \pm 0.12$ & $6.90 \pm 0.20$ \\
Ash Carbohydrate & $7.45 \pm 0.15$ & $4.98 \pm 0.13$ & $5.61 \pm 0.09$ & $5.60 \pm 0.30$ \\
Total & $65.66 \pm 4.33$ & $77.15 \pm 3.01$ & $74.19 \pm 3.21$ & $74.08 \pm 3.06$ \\
\hline
\end{tabular}

Results are presented as Mean $\pm S D, n=$ number of determinations

\section{Discussion}

Several workers have long established that dietary practices affect the plasma lipids and lipoprotein-cholesterol profiles. Following the feeding of peeled grated cocoyam, plantain porridge, pounded yam with plain soup and rat pellets which differed in nutrient content as meals to rats over a 28 day-period, variations in total plasma cholesterol, total plasma triacylglycerol and lipoprotein-cholesterol concentrations have been observed. The total plasma cholesterol level in rats on the peeled grated cocoyam meal $(3.02 \pm 0.26 \mathrm{mmol} / \mathrm{l})$, pounded yam with plain soup meal $(2.13 \pm 0.21$ $\mathrm{mmol} / \mathrm{l}$ ) and plantain porridge meal (2.64 0.04 $\mathrm{mmol} / \mathrm{l}$ ) fell within the range of $2.00-3.00$ $\mathrm{mmol} / \mathrm{l}$, thus supporting the previous results of Umoh (1972). These consistent low level of total plasma cholesterol in test animals may be related to the fact that in all test meals the source of fat was palm oil and analysis of palm oil by Oyenuga (1967) show that it contains more than $50 \%$ unsaturated fatty acids (oleic and linoleic) which have long been known to lower the plasma concentration of cholesterol
(Amstrong et al 1970; Mensink and Katan, 1987; Hegsted et al 1993). However, the higher concentration of total cholesterol in the peeled grated cocoyam fed group compared with other meals in indicative of the higher level of fat in this meal (Table 2).

The lower level of HDL-cholesterol and the higher level of LDL-cholesterol in the peeled grated cocoyam and plantain porridge fed groups, coupled with higher levels of total plasma cholesterol in these groups attracts attention since decreases in HDL-cholesterol and increases in LDL-cholesterol and total cholesterol are positively correlated with the atherosclerotic process (WHO, 2004). The significantly lower $(\mathrm{P}<0.05)$ level of LDLcholesterol, VLDL-cholesterol in the pounded yam with plain soup fed group seem to suggest low atherogenic potential for this meal. The observed similarity in plasma level of triacylglycerol in all groups seems to be due to similarity in the protein contents of these meals. Feeding on protein meals have been shown to increase plasma triacylglycerol concentration (Oliver, 1981). However, the significantly $(\mathrm{P}<$ 
0.05) lower level in the pounded yam with plain soup fed group may be a result of other dietary interactions. Studies by Schaefer (1980) indicate that increase in plasma triacylglycerol are negatively correlated with levels of HDLcholesterol; in this study, all experimental groups recorded positive correlations between their HDL-cholesterol and plasma triacylglycerol level suggesting that the triacylglycerol level in all groups may be within normal limits.

In the strength of the aforegoing, it could be concluded that the pounded yam with plain soup meal possesses lower atherogenic potentials compared to the peeled grated cocoyam and plantain porridge meals.

\section{References}

Armstrong, D. M., Warner, E. D. and Conour, W. E. (1970). Regression of coronary athernoma in rhesus Monkeys. Circ. Res. 27: $59-67$.

Association of Analytical Chemist (1990) Official Methods of Analysis. $20^{\text {th }}$ ed. Washington D.C

Bronte-Steward, B., Keys, A. and Breek, J. F. (1955). "Serum cholesterol, diet and coronary heart disease. An inter-racial survey in the Cape Pennisular" Lancet 2: $1103-1107$.

Burnstein, M. and Samaille, J. (1960). Arapid determination of cholesterol bound to apo A and B lipoproteins. Clin. Chem. Acta. 5:609

Friedewald, W. T., Levy, R. I. and Fredrickson, D. S. (1992) Estimation of the concentration of LDL-cholesterol in plasma without use of ultracentrifuge. Clin. Chem. 18: 499.

Fulton, F. W. (1978) Observed death rates from 196901977 in six regions in the UK, for CHD and cerebrovascular disease. Brit. Heart J. 40. 565.

Grundy, S. M. and Denke, M. A. (1990) Dietary influences and Serum lipid and lipoproteins , J. Lipid. Res. 31: 1149 - 117278.

Hegsted, M. D. , Ausma, L. M.; Johnson, J. A. and Dallal, G. E. (1993) Dietary fat and Serum lipids: an evaluation of the experimental data. Am. J. Clin. Nutr. 57: $875-883$.

Mensink, R. P. and Katan, M. B. (1987). Effect of monosaturated fatty acids versus complex carbohydrates on high density lipoproteins in healthy men and women. Lancet. 1: $122-125$.

Mensink, R. P. and Katan, M. B. (1989) Effect of a diet enriched with monounsaturated or polyunsaturated fatty acids on levels of low-density and high-density lipoprotein cholesterol in healthy women and men. $N$ Engl. J. Med. 321:_436 - 441.

Ogunowo, F. O.; Odesami W, O. and J. J. (1986). Coronary artery pathology of consecutive Nigerians. Trans Roy. Soc. Trop. Med and Hyg. 18: 923 - 926.

Ononogbu, I. C. (1979). Serum cholesterol levels in Nigerian Population Sample. Experientia. 35: 1428 - 1429.

Oyenuga, V. A. (1967). In: Agriculture in Nigeria. An Introduction F. A. O. Rome. Oliver, M. F. (1981) Diet and heart Disease. British Med. Bulletin Vol. 37 (1). $49-58$.

Schaefer, J. A. (1980). CHD prevalence and other clinical feature in familial HDLdeficiency (Trangier disease) Ann. of Int. Med. 93: 261 - 265.

Siedel, J., Rolling, N., Rosehan, P. and Ziegenhorn, J. (1985). Cholesterol. In: Methods of enzymatic Analysis, $3^{\text {rd }}$ ed. Bergmeyer, H.V. (ed), vol, III Metabolic 3, Verlag chanice. pp $19-28$

Stein, K., Langenhoven, M. I., Joubert, G. ; Ghalton, D. O., Bendde, A. J. S. and Rossouw, J, A. (1990). The relationship between dietary factors and serum cholesterol values in the coloured population of Cape Pennisula. S. Afric Med. J. 78:63-67.

Sullivan, D. R., Kruijswijk, Z., West, C. E., Kohlmeier, M. and katan, M. B. (1995). Determination of Serum triglycerides by an accurate enzymatic method not affected by free glycerol: Clin. Chem. 31: $1227-1228$.

Taylor, G. O. and Agbedana, B. O. (1983). “A Comparative study of Plasma HDLcholesterol in two groups of Nigerians in Different socio-economic status" Afr, J. Med. Sci. 12: 23-38.

Taylor, G. O. and Akande, E. O. (1975). Serum lipid in pregnancy and socio-Economic status. Brit. J. Obstet. Gynaecol. 82: 297 302.

Umoh, I. B. (1972). “Changes in nutritive values of some Nigerian diets after Cooking by certain South-Eastern Nigerian traditional Methods". PhD Thesis Department of Biochemistry, University of Ibadan, Nigeria.

William, A. O. (1971) Coronary atherosclerosis in Nigeria. Br. Heart. J. 33: 85 - 100.

World Health Organization (2004) "Facts About Diabetes" WHO information sheet on diabetes. Retrieval on April 26, 2004 form www.who.int/mediacentre/factorsheet/fs 13 8/en/index/html.

Received: 13/2/2007

Accepted:15/3/2007 